\title{
The Integration of m-Learning and Social Nework for Suporting Knowledge Sharing
}

\author{
Pannee Suanpang \\ Faculty of Science \& Technology, Suan Dusit Rajabhat University, Bangkok, Thailand \\ Email: panneessua@dusit.ac.th
}

Received 2012

\begin{abstract}
Mobile learning (m-Learning) is a type of a learning system that combines mobile, computer, and modern educational technologies to facilitate teaching and learning. Social network use Web 2.0 technology to communicate, share and searching information for the students. This paper presents the integration of $\mathrm{m}$-Learning and social network design for supporting the sharing of knowledge. The m-Learning system was developed from IPTV (Suan Dusit Internet Broadcasting: SDIB) to mobile IPTV and extended to $\mathrm{m}$-Learning systems. The prototype was designed by integrating $\mathrm{m}$-Learning system (contents and communication tool) and social networks that support knowledge sharing of the learners. The prototype has been used for teaching and learning and students evaluated the system. The result found that the mLearning system was useful in helping learners to share knowledge and create social interaction.
\end{abstract}

Keywords: m-Learning; Knowledge Sharing; Social Network; Knowledge Management

\section{Introduction}

Mobile learning (m-Learning) is a new type of learning system that combined with mobile communication, mobile computing, network and modern education technologies. (Zhuang, $\mathrm{Xu}, \mathrm{Hu}, \&$ Tian, 2011; Suanpang, 2012 in press). m-Learning is defined as e-Learning using mobile devices and wireless transmission (Hoppe et al., 2003; Chang et al., 2003; Iqbal, \& Qureshi, 2012). Furthermore, m-Learning is define as the acquisition of any knowledge and skill through using mobile technology, anywhere and anytime (Lee \& Chan, 2007). mLearning is becoming popular because the increasing the number of mobile devices (such as smart phones, PDAs and iPads) as well as enhancement in the technological capabilities of these devices. The mobile devices have a variety of capabilities such as making phone calls, recording audio/video, capturing pictures, storing data, accessing the Internet, and connecting with social networks (Maccallam \& Jeffery, 2009; Iqbal, \& Qureshi, 2012). The key attributes of the m-Learning system are spontaneity, personalization, informality, context-sensitivity, portability, ubiquity and pervasiveness (Lee \& Chan, 2007). Also, the m-Learning system facilitates distributed education with the learning activities through a variety of tools which have appropriate pedagogical approaches to collaboration and social interaction (Yang, 2012). Learners can create and share their own knowledge through the use of interactive games, tools for brainstorming, quizzing, and the integration with online management system in classroom (Goh \& Kinshuck, 2006; Iqbal, \& Qureshi, 2012). It linked to social networks (such as Facebook, Twitter, YouTube) passing through smart phone and wireless devices.

Meanwhile, knowledge management especially knowledge sharing, is very important in the field of student's development. Students can create new knowledge from learning and sharing information among friends. The idea is for students to share their knowledge (both explicit and tacit) with friends so as to work in the group project by using the m-Learning and social network systems.

The aim of this study is to integrate m-Learning system delivered through mobile multimedia contents (text, voice, live picture, audio, and video) and to link it to social network applications to support the knowledge sharing of learners.

\section{Knowledge Sharing}

Knowledge sharing is part of knowledge management (KM) process. There are some related theories as follows:

\section{Knowledge}

Knowledge has been defined in several ways. Peter F. Drucker defined it as "the only meaningful resource today" (Drucker, 1993). Nonoka \& Takeuchi (1995) defined it as "one the most important assets for an organization to create value and enhance, sustainable competitive advantage". In this paper, knowledge is defined as the outcome of learning and experiences of the learners that is gained from education.

There are two types of knowledge tacit and explicit. Tacit knowledge is subjective and experiential knowledge that cannot be expressed in words, sentence, numbers or formulas. It included technical skills (craft, know-how) and cognitive skills (belief, image, perspective and mental models). Explicit knowledge is objective and rational knowledge that can be expressed in words, sentence, numbers or formulas. It includes the theoretical approach, problem solving, manuals and databases (Nonoka \& Takeuchi, 1995). However, there is interaction between tacit and explicit knowledge.

\section{Knowledge Conversion Theory}

Nonaka \& Takeuchi (1995) introduced a process of knowledge conversion called the 'SECI' model. The different 'knowledge' could interact and inter-conversion between explicit and tacit knowledge could occur (as seen in Figure 1 below): 


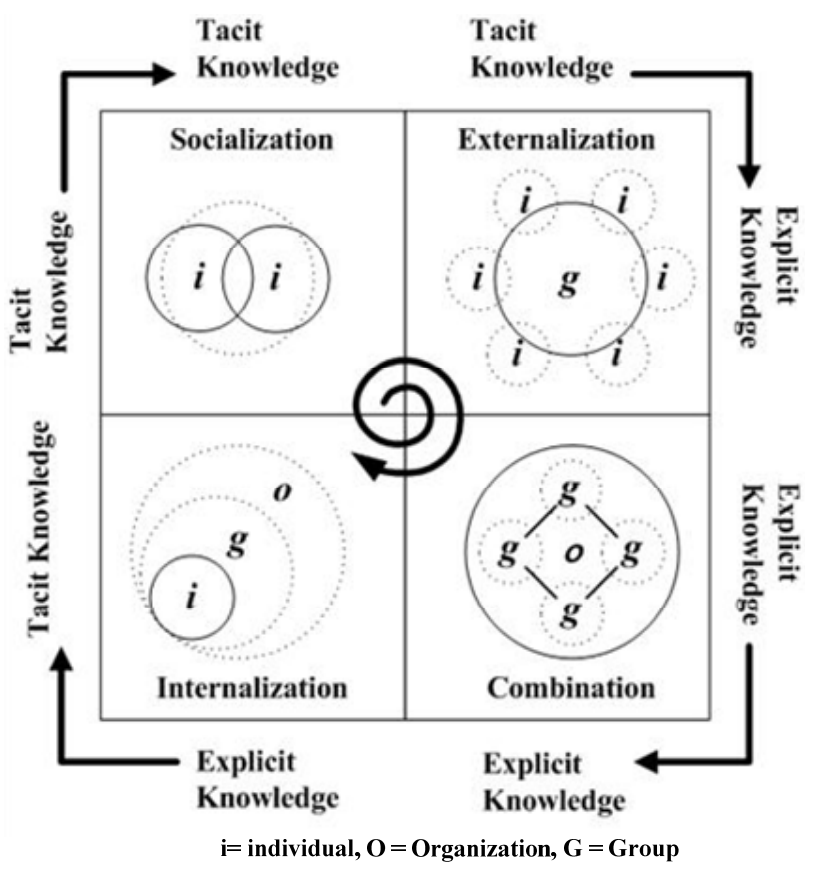

Figure 1.

SECI model.

The SECI model has four dimensions as follows (Dubberly \& Evenson, 2011):

- Socialization (tacit to tacit): This process involves converting new tacit knowledge in order to share experiences through social interactions such as meetings, dialogues, and brainstorming.

- Externalization (tacit to explicit): This process involves converting tacit knowledge to explicit knowledge by publishing and articulating knowledge. Externalization requires learners to communicate or work in groups to share their knowledge.

- Internalization (explicit to tacit): This process involves converting explicit knowledge to tacit knowledge by knowledge receiving and application by an individual.

- Combination (explicit to explicit): This process involves converting explicit to explicit knowledge by organizing, integrating knowledge.

The SECI model is based on the idea that both learning growth and knowledge creation are achieved and completed in social interaction (Edmond, 1999). Knowledge is crated between four dimensions and is a continuous process which works as a spiral and forms for patterns. The spiral of knowledge creation will become bigger and larger (Zhuang, $\mathrm{Xu}, \mathrm{Hu}$, \& Tian, 2011).

Learners in the classroom can develop community of practice $(\mathrm{CoP})$. $\mathrm{CoP}$ consists of group of people with the same interest, same target, and the same job discussing and communicating issues of common concern to promote knowledge sharing and knowledge transmission (Barth, 2003).

\section{Student's Knowledge Sharing}

Knowledge sharing is another type of knowledge passing through which the learner gains both explicit and tacit knowledge (Alavi \& Leidner, 2001; Davenport \& Prusak, 1998; Tiwana, 2000; Ward \& Aurum, 2004). Learners can create new knowledge from knowledge sharing by externalization and internalization via communication. Learner's knowledge sharing model is shown in Figure 2 (Jackson \& Klobas, 2008):

\section{The Development of $\mathbf{m}$-Learning System}

\section{Related Work}

The m-Learning system was a further development of the mobile IPTV of Suan Dusit Internet Broadcasting (SDIB). SDIB was the IPTV of Suan Dusit Rajabhat University. The IPTV has goals of increasing educational opportunities for student in rural areas and to support lifelong learning and education for adults throughout Thailand. The system broadcasted four channels and the content was transmitted both as audio and video. Channel 1 broadcast teaching and learning activities at Sa-Tid-La-OrU-Tid primary school. Most of the contents were useful for teachers in early childhood care centers, of which there were about 17,000 in Thailand (Suanpang, 2009). The SDIB pilot project provided TV, set top box and ADSL for 80 pilot schools around Thailand. The result of the teacher's evaluation using the SDIB system found that teachers had a high satisfaction with the SDIB system (Suanpang, Termboonpasert, Kantamanoon \& Regittinun, 2010). Moreover, the SDIB strategic plan 2012-2015 was developed in which combined four organizational level strategies and 15 projects (Suanpang 2012b; Suanpang, 2012c). The mobile IPTV was a further development of IPTV which could broadcast its content both live and video on demand using both mobile and web browser (Suanpang, 2012 in press)

\section{m-Learning Systems Design}

According to knowledge sharing of the students, m-Learning system should include various methods such as resources, knowledge, information, and experience. The process of knowledge sharing is obtaining and using knowledge (Zhuang, Xu, Hu, \& Tian, 2011). Therefore, the design of m-Learning should be integrated with social network tools in order to provide a knowledge sharing platform and environment. In traditional learning, learners share their knowledge among friends through meetings, group learning and other activities. However, in the $\mathrm{m}$-Learning context, learners share their knowledge by using technology to communicate which each other such as through short message (SMS), e-mails, telephone conversations, video, discussion broads, and comments on social network websites.

The m-Learning system was designed and developed as a prototype. There are 4 steps of prototyping (Laudon \& Laudon, 2012)

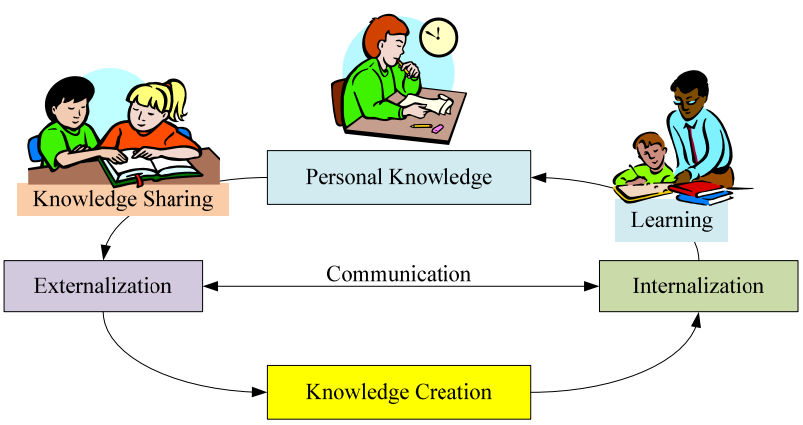

Figure 2.

Knowledge sharing process. 
- Step 1: identify user's requirements by collected data from interviewing learners and teachers who will use the m-Learning system.

- Step 2: develop initial prototype.

- Step 3: use the prototype used by teachers and learners in Strategic Information Planning for Organization Course at Suan Dusit Rajabhat University as the pilot project for 10 weeks.

- Step 4: revise and enhance the prototype.

The m-Learning prototype was designed based on knowledge sharing shown in Figure 3.

The design of the $\mathrm{m}$-Learning prototype consisted of learning content and communication tools. Learning contents included of e-books, PowerPoint presentation, quizzes, videos, and case studies of the Strategic Information Planning for Organization subject. Learners created their own content such as post their group assignment in the m-Learning system. All the content was provided via a website from which people can download and upload their own contents. Communication tools in m- Learning that integrated with social network tools included blogs, mobile IPTV (for watching video of the project/case study which were also posted on YouTube), discussion broad (on Facebook), short message (on Twitter, and mobile phones).

\section{Using m-Learning System in Class}

Learners were arranged to work in group projects to develop 'Information Technology Strategic Plan' to support small businesses (such as bakery shops, rental video shops, online clothing shops, online flower shops, etc). The project required the learners to work in group with eight people in each group. Each group needed to analysis business (vision, mission, organization chart, SWOT analysis, development strategy, financial analysis, etc) and information technology planning (hardware, software, networking, database, and people ware) for those businesses. Therefore, learners were required to access learning materials from the m-Learning system, develop their business

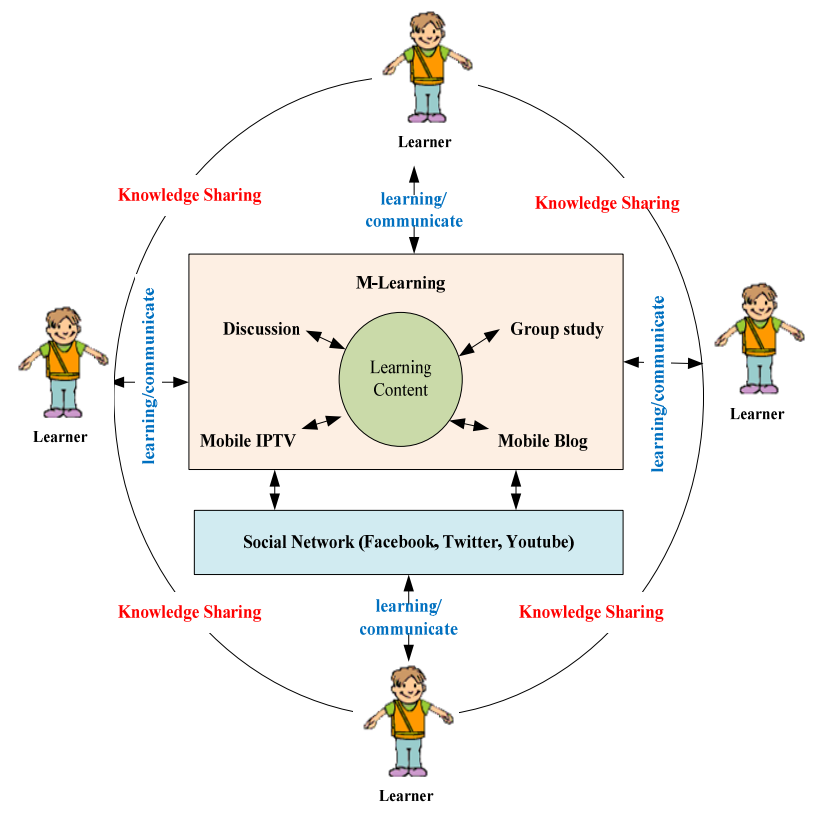

Figure 3.

m-Learning system design. plan and IT plan, design a web, develop social networks to support their project, send texts, take pictures of the physical location, and develop 3D model to simulate the shop that they designed. After they finished their projects, they were required to upload their reports, video, 3D-designed shop, website links and social networks to the m-Learning system.

Figure 4 shows examples of the learner's work project:

\section{m-Learning System Evaluation}

The m-Learning system was evaluated through both quantitative (questionnaires) and qualitative (in-depth interviews) approaches. There were 53 learners enrolled in Strategic Information Planning for Organization course in semester one of the 2012 academic year. The m-Learning system was used for 10 weeks. At the end of the course, learners evaluated the mLearning system through questionnaires and interviews.

The questionnaire was divided into two parts: demographic information of the learners and their attitude towards the use of m-Learning system to share knowledge. There were four dependent variables: usefulness (U), ease of use (EU), learning interaction (LI) and knowledge sharing (KS). Usefulness (U) consisted of four items (adapted from Venkatesh et al., 2003; Iqbal, \& Qureshi, 2012) which focused on m-Learning system's increase in effectiveness. Ease of use (EU) consisted of five items (adapted from Venkatesh et al., 2003; Iqbal, \& Qureshi, 2012) and focused on how easy to use m-Learning system. Learning interaction (LI) consisted of three items that focused on how classmates and teachers interact. Knowledge sharing (KS) consisted four items which focused on how learners use the m-Learning system to share their knowledge. While interviewing the learners, un-structured question were used.

\section{Results}

The demographic profile of the students is given in Table $\mathbf{1 .}$

The descriptive statistics from the m-Learning evaluation is given in Table 2.

Figure 5 shows the results of the evaluation of using mLearning.

The results showed that the highest score (means $=3.19$ ) was knowledge sharing. The learner used $\mathrm{m}$-Learning for sharing knowledge among classmates and teachers. Here are some comments to illustrate knowledge sharing as follows:

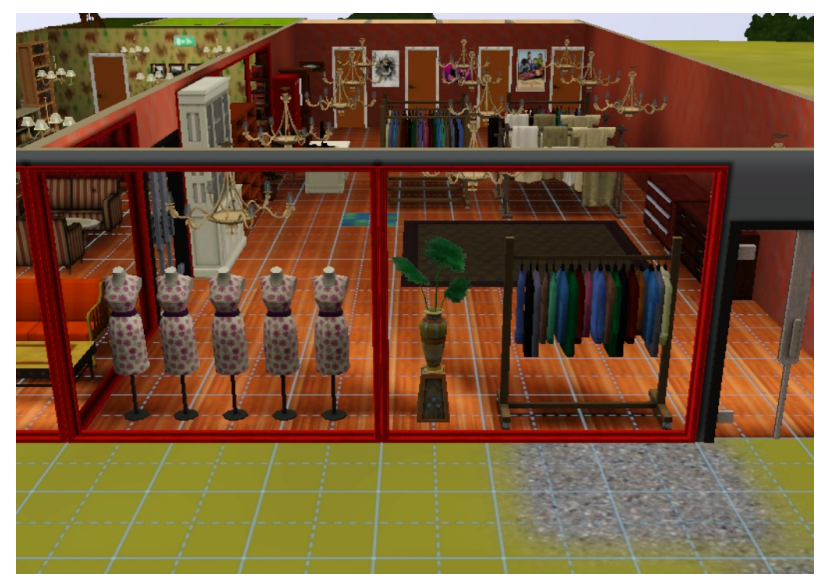

Figure 4.

Example of 3D-designed shop. 
Table 1.

Demographic profiles of learners.

\begin{tabular}{clcc}
\hline \multirow{2}{*}{ Items } & \multicolumn{3}{c}{ Student Profile } \\
\cline { 2 - 4 } & & Frequency & Percent \\
\hline \multirow{2}{*}{ Gender } & Male & 33 & 62.26 \\
& Female & 20 & 37.74 \\
& Total & 53 & 100.00 \\
& Smart phone & 40 & 75.47 \\
Mobile & PDA, iPad & 8 & 15.09 \\
device & Both smart phone and & 5 & 9.43 \\
& PDA/iPad & & \\
& Total & 53 & 100.00 \\
Internet & Prepaid & 50 & 94.34 \\
plan & Postpaid & 3 & 5.66 \\
& Total & 53 & 100.00 \\
\hline
\end{tabular}

Table 2.

Descriptive statistics of evlaution of m-Learning.

\begin{tabular}{|c|c|c|c|}
\hline \multirow{2}{*}{ Items } & \multicolumn{3}{|l|}{ Student attitude toward of using $\mathrm{m}$-Learning } \\
\hline & & Mean & SD \\
\hline \multirow{4}{*}{$\mathrm{U}$} & -m-Learning tools help accomplish task more & 2.78 & 0.98 \\
\hline & $\begin{array}{l}\text { quickly } \\
\text {-m-Learning increase job performance }\end{array}$ & 3.12 & 1.26 \\
\hline & $\begin{array}{l}\text {-use of m-Learning resulted in increase } \\
\text { productivity }\end{array}$ & 3.25 & 1.33 \\
\hline & - use of m-Learning will increase effectiveness & 3.37 & 1.35 \\
\hline \multirow{5}{*}{ EU } & & 3.06 & 0.96 \\
\hline & $-\mathrm{m}$-Learning makes learning easier & 3.45 & 1.11 \\
\hline & $-\mathrm{m}$-Learning is useful for learners & 3.20 & 1.25 \\
\hline & $\begin{array}{l}\text {-it is easy to access information from m-Learning } \\
\text {-it is easy to use m-Learning tools to } \\
\text { communicate with freinds }\end{array}$ & 3.12 & 1.32 \\
\hline & -it is easy to become skillful at using m-Learning & 2.99 & 1.36 \\
\hline \multirow{3}{*}{ LI } & $\begin{array}{l}\text {-I use m-Learning to communicate and share } \\
\text { knowledge with friends in class often }\end{array}$ & 3.55 & 0.89 \\
\hline & $\begin{array}{l}\text {-I use m-Learning to communicate with the } \\
\text { teacher often }\end{array}$ & 3.45 & 1.25 \\
\hline & $\begin{array}{l}\text {-I awlays use m-Learning to interact with my } \\
\text { learning }\end{array}$ & 3.23 & 1.19 \\
\hline \multirow{3}{*}{ KS } & $\begin{array}{l}-\mathrm{m} \text {-Learning use for sharing knowledge with } \\
\text { friends }\end{array}$ & 3.35 & 1.22 \\
\hline & $\begin{array}{l}\text {-m-Learning can create community of practice for } \\
(\mathrm{CoP}) \text { learners }\end{array}$ & 3.12 & 1.14 \\
\hline & -m-Learning help learners to create knowledge & 3.09 & 1.36 \\
\hline Overall & Satisfaction of using m-Learning & 3.55 & 1.10 \\
\hline
\end{tabular}

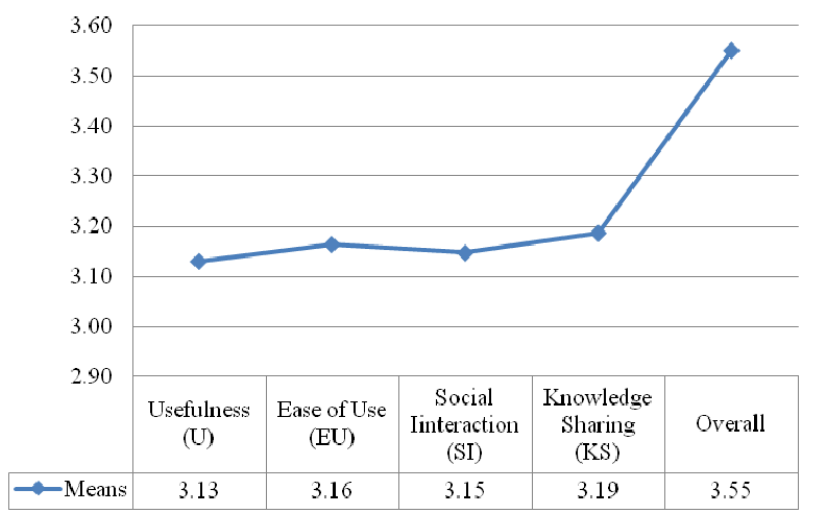

Figure 5.

Result of m-Learning evaluation.
"We are always on FB to sharing information and tracking work between the group members".

"We sharing information about how to develop business plan because this is new for us. We shared picture, information, video clip to other group via m-Learning and Facebook".

"The m-Learning system helped us to sharing knowledge about how to develop business and IT strategic plan a lot. We really like it.

Secondly, learners found that the m-Learning system was easy to use (means $=3.16$ ). The m-Learning system made their learning easier and more effective. They could get information from m-Learning everywhere and any time that they wanted. Here are further some comments to illustrate the ease of use for m-Learning as follows:

"I have to change mobile from $B B$ to iPhone to use in this course to catch up friends". I think I use mobile phone to be more efficacy, use almost all the function not only entertainment but I use it for study too. I felt very proud of myself."

"We like to use mobile phone take pictures of the slide presentation of the teacher sometimes that we cannot catch up lecture".

"I think m-Learning system is easy to use because I always use smart phone for connect to Internet to searching information while lecturing. It is very convenience."

"We got computer notebook that provided by the university. But it quite heavy that why we bring it to class sometimes. But we like to use mobile phone because it very convenience and have all function such as checking e-mail, SMS, and Facebook that we want to communication and access to m-Learning system."

Third, learners used m-Learning to develop social interaction $($ means $=3.15)$. They used m-Learning system for sharing knowledge and communicating with their friends. Also the system developed community of practice through which they can create knowledge from the social interaction. Here are some comments to illustrate the social interaction of m-Learning as follows:

"We always communicate to group members especially when near the deadline of submitting the project. We need to help each other to finish work. That way we talk a lot to exchange our information"

"We always comment and send message via m-Learning system and share information with friends in Facebook. This is very good way to communication because everyone has Facebook."

Finally, learner's perception was that m-Learning was useful (means $=3.13$ ). They think that $\mathrm{m}$-Learning system helped them to accomplish tasks more quickly and increase their job performance, productivity and effectiveness. Here are some comments to illustrate the usefulness of m-Learning as follows:

"We like m-Learning system because it helped us to work in project more easily and productivity."

"This system is very cool, it help us to work easily and effective."

Overall, students were very satisfied (means $=3.55$ ) with the $\mathrm{m}$-Learning system and recommended using this system for other subjects, especially for their senior projects.

\section{Conclusion}

The m-Learning system has the potential to become an effective means for providing education rather than by the traditional 
method. m-Learning can create knowledge management for learners. This paper illustrated the design of the m-Learning system which when integrated with social networks helps learners to develop knowledge sharing. The concept and instructional issues related to $\mathrm{m}$-Learning design are evolving (Zhuang, Xu, Hu, \& Tian, 2011; Suanpang, 2012 in press). The m-Learner prototype included contents and communication tools. The prototype was used and evaluated. The results found that the system helps learners to share knowledge and crate social interaction as well as being easy to use and useful for them.

\section{Limitations of the Research and Future Work}

$\mathrm{m}$-Learning was developed as a prototype which focused on knowledge sharing in this study. Therefore, it should develop as the full functional m-Learning system that can support knowledge management including knowledge obtaining, knowledge storage, knowledge sharing, knowledge usage, and knowledge renewal. In addition, future studies can focus on its use in specific disciplines such as humanities, education, engineer, management, business, and others to figure out the ideal disciplines for adoption of this medium of education. Additionally, future study should focus on pedagogy for m-Learning to improve learning effectiveness.

\section{Acknowledge}

The author would like to thank the Office of Academic Resource and Information Technology (ARIT) at Suan Dusit Rajabhat University for providing network infrastructure to support m-Learning system.

\section{REFERENCES}

Alavi, M.D., \& Leider, D. E. (2001). Knowledge management and knowledge management systems: Conceptual foundations and research issue. MIS Quarterly, 25(1), 107-113.

Barth, S. (2003). Creating and Managing the Knowledge-Based Enterprise. Knowledge Management World Magazine, January, 12 (1).

Chan, A. \& Lee, M. J. (2007). Pervasive, lifestyle-integrated mobile learning for distance learners. The Journal of Open and Distance Learning, 22(3), 201-218.

Chang, C. Y., Sheu., J.P., \& Chan, T. W. (2003). Concept and design of ad hoc and mobile classroom, Journal of Computer Assisted Learning, 19 (3), 336-346.

Davenport, T. H., \& Prusak, L. (1998). Working knowledge: How organizations manage what they know, Boston: Harvard Business School Press.

Drucker, P. F. (1993). Postcapitalist Society. New York: HerperCollins Publishers.

Dubberly, H. \& Evenson, S. (2011). Design as Learning or Knowledge Creation the SECI Model, Interaction, January- February, 75-79.

Edmond, V. F. (1999). Knowledge Mapping Getting Started with Knowledge Management, Information Systems Management, 16(4),
16-23.

Goh, T., \& Kinshuk, D. (2006). Getting ready for mobile learning adaptation perspective. Journal of Educational Multimedia and Hypermedia, 15(2), 175-198

Hoppe, H. U., Jointer, R., Milrad, M., \& Sharples, M. (2003). Guest editorial: Wireless and mobile technologies in education. Journal of Computer Assisted Learning, (19), 255-259.

Iqbal, S. \& Qureshi, I. (2012). M-learning Adoption: A Perspective from a Developing Country. The International Review of Research Open and Distance Learning. 13 (3), 147-164.

Jackson, P., and Klobas, J. (2008). Transitive memory systems in organizations: implications for knowledge directories. Decision Support Systems, (44), 409-424.

Laudon, K. C., \& Laudon, J. P. (2012). Management Information Systems Managing in the Digital Firm (12 ${ }^{\text {th }} e d$.). London: Person education.

MacCallum, K., \& Jeffrey, L. (2009). Identifying discriminating variable that determine mobile learning adoption by educators: An initial study. In Same place, different space. Proceeding ascilite Auckland, 2009. URL (last checked 10 September 2012)

http://www.ascilite.org.au/conferences/auckland09/procs/maccallum. pdf.

Nonaka, I. and Takeuchi, H. (1995). The Knowledge-Creating Company. New York: Oxford University Press.

Suanpang, P. (2009). Suan Dusit Internet Broadcasting (SDIB)-Educational Innovation in Knowledge-Based Society. Journal of the Computer; the Internet and Management, 17, 31.1-3.15.

Suanpang, P. (2012 a). Internet Broadcasting for Developing Teacher in Early Childhood Care Centers in Thailand: Phase II Strategic and Development Planning, Information Technology Journal, 8 (1), 87-104.

Suanpang, P. (2012 b). Internet Broadcasting for Developing Teacher in Early Childhood Care Center in Thailand:- Strategic and Developing Planning. Proceeding of the World Conference on Educational Media and Technology, USA.

Suanpang, P. (2012, in press).The Development IPTV to Mobile IPTV Implication for Teaching and Learning. Proceeding of the International Conference on ICT Convergence 2012 (ICTC 2012), Korea.

Suanpang, P., Termboonpasert, J., Kantamanoon, P., \& Rengittinun, (2010). Internet Broadcasting: An Educational Innovation for Developing Teacher in Early Childhood Care Center all over Thailand: Phase 1, SDU Research Journal, 3 (1), 87-104.

Tiwana, A. (2000). The knowledge management toolkit: Practical techniques for building a knowledge management system. Upper Saddle River, NJ: Prentice Hall.

Ward, J., \& Aurum, a. (2004). Knowledge Management in software engineering: Describing the process. Proceeding of the $15^{\text {th }}$ Australian Software Engineering Conference (ASWEC 2004), Melbourne, Australia.

Venkatesh, V., Morris, M. G., Davis, G. B. \& David, F.D. (2003). User acceptance of information technology: Toward a unified view. MIS Quarterly, 27(3), 425-78.

Yang, Q. (2012) Applying Wireless Classroom to Build a Holiday Interactive Learning Environment, Creative Education, 3(4), 527-532.

Zhuang, S., Xu, H., Hu, L., \& Tian, Y. (2011). M-Learning Design Based on Personal Knowledge Management. Proceeding of the 2011 International Conference on Information Management, Innovation Management and Industrial Engineering, China, 135-138. 